\title{
Konversi Antena Mimo 2x2 Frekuensi 2,4 Ghz Menjadi 5,5 Ghz Menggunakan Patch Bowtie Berbasis Dual Slot Segi Empat dan Single Slot Segitiga
}

\section{The Conversion of Mimo Antenna 2x2 Frequency 2.4 Ghz To 5.5 Ghz Using Patch Bowtie Based On Rectangular Dual Slot and Single Triangle Slot}

\author{
M.Reza Hidayat ${ }^{1 *}$, Reza Agung Permana ${ }^{2}$, Susanto Sambari ${ }^{3}$ \\ 1,2,3 Universitas Jenderal Achmad Yani Jurusan Teknik Elektro \\ Jl. Terusan Jend. Sudirman, Cibeber, Kec. Cimahi Sel., Kota Cimahi, Jawa Barat 40531, (022) 6656190 \\ rezaagungp94@gmail.com ${ }^{1 *}$, mreza@lecture.unjani.ac.id ${ }^{2}$, Santo.sambari@gmail.com ${ }^{3}$
}

\begin{abstract}
Abstrak - Perkembangan antena radar semakin cepat dan beragam, salah satunya adalah antena MIMO (multiple output). Antena MIMO banyak digunakan untuk teknologi $5 G$ karena efisiensi spectral dan fekuensi yang tinggi. Antena MIMO juga merupakan suatu sistem yang menggunakan multi antena baik pengrim (Transmitter) maupun penerima (receiver) yang bisa mengatasi kelemahan pada sistem komunikasi wireless. Penelitian ini merancang sebuah antena mikrostrip MIMO $2 X 2$ dengan menggunakan patch bowtie untuk mengkonversi frekuensi dari 2,4 GHz menjadi 5,5 GHz dengan menambahkan dual slot segiempat dan single slot segitiga. Hasil simulasi menunjukkan penambahan dual slot segiempat dan single slot segitiga pada patch antena bowtie dapat menggeser frekuensi kerja dari 2,4 GHz menjadi 5,5 GHz. Dari hasil simulasi antena MIMO $2 X 2$ didapatkan nilai return loss $S 11$ sebesar -46,5 dB, insertion loss 221 sebesar -25,2 dB, bandwidth sebesar 192,2 MHz, VSWR sebesar 1,00 dan gain sebesar 3,11 dBi. Hasil dari pengukuran antena MIMO menunjukkan perbedaan dari parameter antena 1 dan 2. Hal ini disebabkan adanya ketidaksamaan ukuran dari antena 1 dan antena 2. Pengukuran nilai return loss untuk antena 1 yaitu sebesar $-22,32 \mathrm{~dB}$ dan $-15,63 \mathrm{~dB}$ untuk antena 2 . Hasil pengukuran insertion loss antena 1 dan 2 memiliki nilai yang sama yaitu -43,5 dB dan untuk lebar bandwidth memiliki perbedaan nilai yaitu $50 \mathrm{MHz}$ untuk antena 1 dan $100 \mathrm{MHz}$ untuk antena 2. Pengukuran nilai VSWR 1 didapatkan nilai sebesar 1,96, VSWR 2 sebesar 1,41.
\end{abstract}

Kata Kunci: $M I M O$, wifi, mikrostrip, antena patch bowtie

Abstract - The development of radar antennas is getting faster and more diverse, one of which is the MIMO (multiple output) antenna. MIMO antennas are widely used for 5G technology because of their high spectral efficiency and frequency. MIMO antenna is also a system that uses multiple antennas, both transmitter and receiver which can solving the weaknesses in wireless communication systems. The research designed a $2 X 2$ MIMO microstrip antenna using a patch bowtie to convert the frequency from

TELKA, Vol.7, No.2, November 2021, pp. 161 173

ISSN (e): 2540-9123

ISSN (p): 2502-1982 
$2.4 \mathrm{GHZ}$ to $5.5 \mathrm{GHz}$ by adding dual rectangular slots and single triangular slots. The simulation results show that the addition of dual rectangular slots and single triangular slots on the patch bowtie antenna can shift the working frequency from $2.4 \mathrm{GHz}$ to $5.5 \mathrm{GHz}$. From the simulation results of MIMO $2 X 2$ antenna, the return loss value of $S 11$ is $-46.5 \mathrm{~dB}$, insertion loss $S 21$ is $-25.2 \mathrm{~dB}$, bandwidth is $192.2 \mathrm{MHz}$, VSWR is 1.00 and gain is $3.11 \mathrm{dBi}$. The results of the MIMO antenna measurements show differences in the parameters of antennas 1 and 2. This is due to the difference size of antenna 1 and antenna 2. The measurement of the return loss value for antenna 1 is $-22.32 \mathrm{~dB}$ and $-15.63 \mathrm{~dB}$ for antenna 2 The results of the insertion loss measurements for antennas 1 and 2 have the same value, which is $-43.5 \mathrm{~dB}$ and for the width of the bandwidth has a different value, $50 \mathrm{MHz}$ for antenna 1 and $100 \mathrm{MHz}$ for antenna 2. Measurement of the value of VSWR 1 obtained a value of 1.96, VSWR 2 is 1.41.

Keywords: bowtie patch antenna, microstrip, MIMO, wifi.

\section{Pendahuluan}

Antena MIMO banyak digunakan untuk teknologi 5G karena efisiensi spectral dan fekuensi yang tinggi. Antena MIMO juga merupakan suatu sistem yang menggunakan multi antena baik pengrim (Transmitter) maupun penerima (receiver) yang bisa mengatasi kelemahan pada sistem komunikasi wireless. Antena MIMO dapat melipat gandakan kapasitas serta kemampuan mengirimkan dan menerima lebih banyak lagi data secara bersamaan. Meningkatnya kebutuhan transfer data cepat dan dalam jumlah yang banyak pada pengguna Wifi mendorong munculnya teknologi dan standar baru. IEEE telah merilis standar $802.11 \mathrm{n}$, dengan perubahan dari standar sebelumnya yaitu data rate lebih tinggi, bandwidth lebih lebar dan mendukung teknologi MIMO[1] - [3].

Kebutuhan transfer data cepat dengan jumlah yang besar pada pengguna wifi meningkat mendorong munculnya teknologi dan standard baru pada wifi. IEEE telah merilis standard $801.11 \mathrm{n}$ dengan perubahan dari standard sebelumnya dengan data rate lebih tinggi dan bandwidth yang lebar dan mendukung teknologi MIMO. Dari hasil penelitian, Antena Mikrostrip MIMO 2x2 dapat bekerja dengan baik dibandingkan dengan Antena Dipole Default berdasar hasil pengujian level sinyal dan kecepatan transfer data baik dalam keadaan LOS maupun NLOS[4]. Penelitian kedua mengenai perkembangan Radio over fiber pada sisi antena menggunakan Teknik multiple output atau MIMO. Dari hasil penelitian antena MIMO 2X2 menghasilkan performa terbaik dalam hal kapasitas kanal sehingga terjadi efisiensi bandwidth karena memiliki 2 antena pemancar. Jadi antena ini sangat optimal jika diaplikasikan pada radio over fiber pada jaringan LTE[5]. Penelitian ketigga menggunakan teknologi MIMO pada multi antena baik disisi transmitter maupun receiver untuk mengatasi multipath fading. Selain itu teknologi MIMO juga memiliki daya tembus penghalang yang baik serta menjangkau daerah yang lebih luas jika bekerja pada frekuensi 2,4 GHz[6]. Penelitian keempat MIMO (Multiple Input Mulitple Output) merupakan teknologi komunikasi wireless yang mendukung terhadap LTE (Long Term Evolution) dalam pengembangan generasi ketiga dalam sistem komunikasi seluler. Jenis antenanya ialah jenis mikrostrip yang mempunyai dimensi yang lebih kecil dibanding antena lainnya[7]. Penelitian kelima tentang antena mikrostrip adalah antena yang terdiri dari dua lapisan konduktor yang berfungsi sebagai elemen peradiasi dan groundplane. Diantara kedua konduktor tersebut terdapat bahan substrat dengan nilai konstanta dielektrik dalam rentang $2,2 \leq \varepsilon_{\mathrm{r}} \leq 12$. Konstanta dielektrik yang rendah dan substrat yang tebal menghasilkan bandwidth yang besar dan efisiensi yang tinggi, sehingga dimensi antena menjadi lebih besar. Sebaliknya konstanta dielektrik yang rendah dan substrat yang tipis akan menghasilkan bandwidth yang lebih kecil dan efisiensi yang rendah, dimensi antena akan lebih kecil[8]. Penelitian berikutnya merancang antena fleksibel duroid rogger $3003 \mathrm{C}$ dengan frekuensi 2,455 GHz. Antena dengan bahan fleksible bisa digunakan untuk komunikasi saat dan pasca terjadi bencana alam seperti gempa dan erupsi gunung berapi [9].

Oleh karena itu pada penelitian ini juga dilakukan miniturisasi antena MIMO 2X2 untuk frekuensi kerja $5 \mathrm{GHz}$ dengan observasi pengaruh dari penambahan slot di bowtie pada antenna 
dalam bentuk segitiga (single) serta dual slot segiempat dan mengamati karakteristik dari parameter antena yakni Voltage standing wave ratio (VSWR), return loss, pengutan, dan juga bandwidth dari antena MIMO 2X2 ketika ukuran dari slot tersebut diubah-ubah. Kemudian merealisasikan antena hasil simulasi ke dalam hardware dan membandingkan hasil pengukuran dengan hasil simulasi.

\section{Metode Penelitian}

\subsection{Diagram Blok Sistem}

Gambar 1. merupakan diagram blok sistem antena, karena yang dibuat adalah antena pengirim, maka yang dibahas adalah bagian pengirim yaitu yang didalam kotak merah.

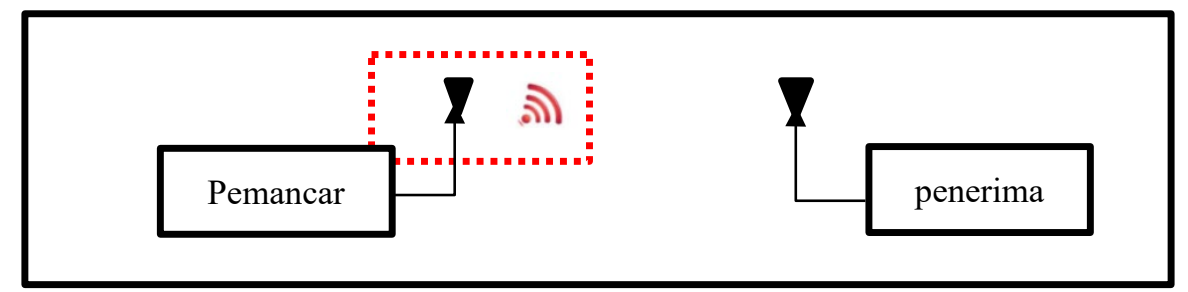

Gambar 1. Diagram blok sistem.

\subsection{Diagram Alir}

Diagram alir penelitian mengacu pada Gambar 2.

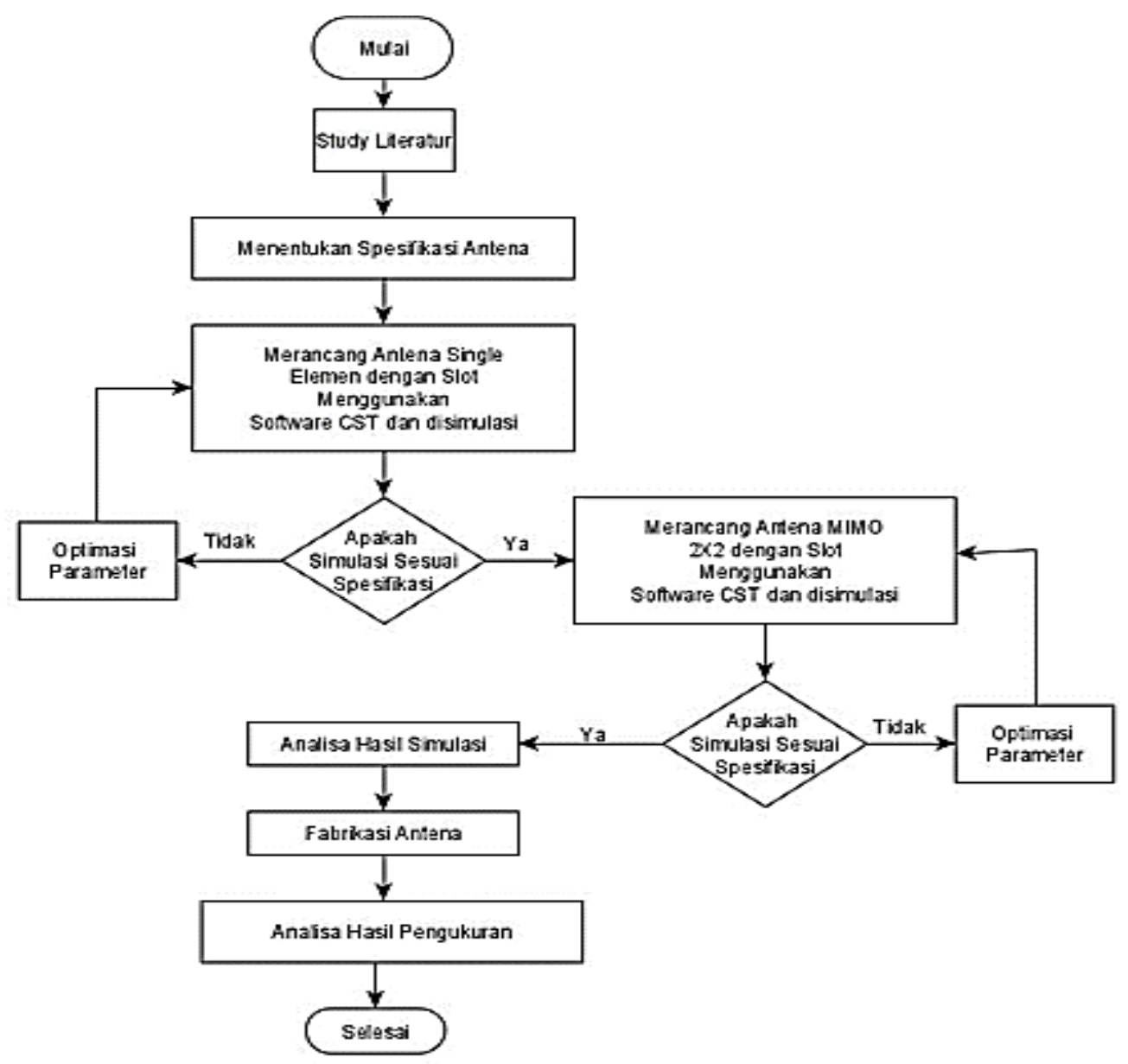

Gambar 2 Diagram alir perancangan antena. 
Perancangan antena mikrostrip bowtie MIMO dibuat dengan beberapa tahapan agar perancangan dapat dilakukan secara sistematis. Tahapan perancangan dilakukan dan dijelaskan dengan diagram alir pada Gambar 2. Dalam menentukan perancangan suatu antena harus menentukan spesifikasi antena terlebih dahulu, dilanjutkan dengan menghitung dimensi antena dan kemudian disimulasikan menggunakan software CST suite 2019. Setelah mendapatkan hasil antena yang diinginkan, antena bisa langsung difabrikasi sesuai dengan dimensi yang telah ditentukan dalam simulasi menggunakan software CST. PEngujian dilakukan dengan mengukur menggunakan alat vector network analyzer (VNA) untuk megetahui hasil dari SParameter dan VSWR dari antena yang telah difabrikasi seperti pada Gambar 2.

\subsection{Perancangan Antena}

\subsubsection{Spesifikasi antena}

Seperti yang telah dijelaskan pada diagram alir pada Gambar 2, spesifikasi antena harus ditentukan dengan mengikuti standard dari aplikasi yang akan digunakan. Tabel 1 menampilkan spesifikasi yang menjadi acuan untuk perancangan yang dilakukan.

Tabel 1. Spesifikasi antena.

\begin{tabular}{cc}
\hline Parameter & Spesifikasi wifi 802.11n \\
\hline Band frekuensi & $2 \mathrm{GHz}-6 \mathrm{GHz}$ \\
Bandwith & $\geq 100 \mathrm{MHz}$ \\
VSWR & $\leq 2$ \\
Return loss & $\leq-10 \mathrm{~dB}$ \\
Gain & $\geq 2 \mathrm{dBi}$ \\
Pola radiasi & Unidirectional \\
\hline
\end{tabular}

\subsubsection{Karakteristik Bahan}

Karena yang dibuat adalah antena mikrostrip, jadi bahan yang digunakan adalah material tembaga (copper). Material ini digunakan untuk bahan dari patch dan goundplane dan untuk substrat digunakan bahan dari material FR-4 epoxy.

\subsubsection{Kontruksi Antena}

Kontruksi antena yang dipilih adalah antena mikrostrip bowtie MIMO 2X2 dengan menambahkan persegi pada ujung antena dan menambahkan dual slot persegi dan single slot segitiga. Spesifikasi antena mikostrip bowtie MIMO 2X2 diharapkan bisa memenuhi standard dari wifi 802.11n dengan frekuensi 5,5 Ghz. Rancangan antena ditampilkan pada Gambar 3.

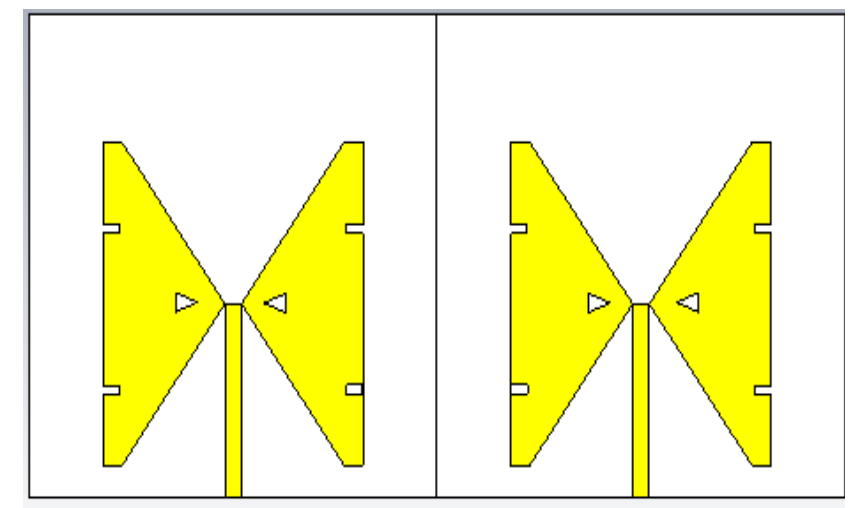

Gambar 3. Rancangan antena MIMO 2X2 Bowtie. 


\subsection{Perhitungan Dimensi Antena}

Dalam pembuatan antena mikrostrip bowtie yang pertama dihitung adalah lebar dari patch antena atau $\mathrm{W}$ dengan menggunakan persamaan (1).

$$
w=\frac{c}{2 f_{\mathrm{o}} \sqrt{\frac{\varepsilon_{r}+1}{2}}}
$$

dimana didapatkan lebar dari patch antena yaitu sebesar 38,3 mm. Kemudian menghitung konstanta dielektrik $\left(\varepsilon_{\mathrm{reff} f}\right)$ dengan menggunakan persamaan (2).

$$
\varepsilon_{r e e} f f=\frac{\varepsilon_{\mathrm{r}}+1}{2}+\frac{\varepsilon_{\mathrm{r}}-1}{2}\left(\frac{1+12 h}{w}\right)^{-1 / 2}
$$

dari hasil persamaan diatas didapatkan konstanta dielektrik sebesar 2,271. Selanjutnya menghitung $\Delta \mathrm{L}$ dengan menggunakan persamaan (3).

$$
\Delta L=0.412 h\left[\frac{\varepsilon_{\mathrm{re}} f f+0.3\left(\frac{w}{h}+0.264\right)}{\varepsilon_{\mathrm{re}} f f-0.258\left(\frac{w}{h}+0.8\right)}\right]
$$

dan didapatkan nilai sebesar $0,883 \mathrm{~mm}$. Tahap selanjutnya yaitu menghitung panjang efektif dari antena $\left(L_{\mathrm{e} f f}\right)$ dengan menggunakan persamaan (4).

$$
L=L_{e} f f-2 \Delta L
$$

dengan mendatkan nilai sebesar $42,7 \mathrm{~mm}$. Setelah nilai $\Delta \mathrm{L}$ dan $\left(L_{\mathrm{e} f f}\right)$ sudah diperoleh tahap selanjutnya adalah mencari panjang sebenarnya dari antena dengan menggunakan persamaan (5).

$$
L_{\mathrm{e}} f f=\frac{c}{2 f_{\mathrm{o}} \sqrt{\varepsilon_{\mathrm{re}} f f}}
$$

dan diperoleh nilai sebesar 42,69 $\mathrm{mm}$. selanjutnya adalah menghitung panjang gelombang dengan menggunakan persamaan (6).

$$
\lambda=\frac{c}{2 f \sqrt{\varepsilon_{\mathrm{re}} f f}}
$$

dan mendapatkan nilai lamda sebesar $75,57 \mathrm{~mm}$. sedangkan untuk panjang efektif yaitu $1 / 2 \lambda$ sebesar 36,25 mm[10]. Berdasarkan perhitungan diatas didapatkan hasil seperti Gambar 4.

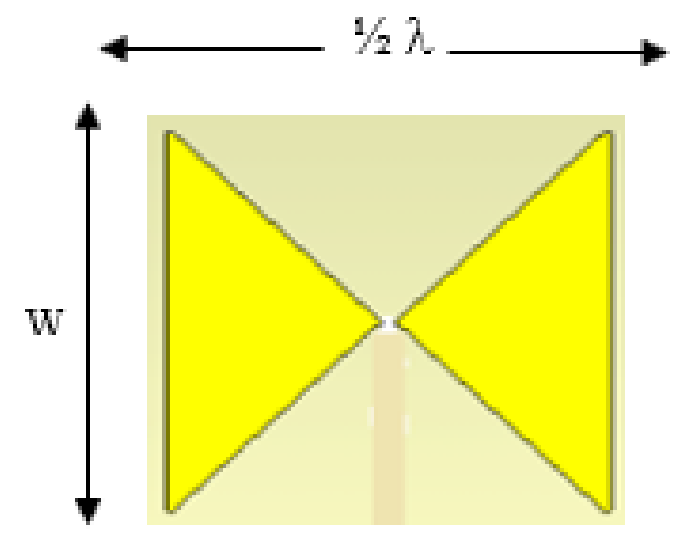

Gambar 4. Panjang $1 / 2 \lambda$ pada Antena Mikrostrip Bowtie. 


\subsubsection{Substrate dan Groundplane}

Antena yang dibuat adalah MIMO 2X2 sehingga substrate dan groundplane dibuat berbentuk persegi panjang. Untuk mengetahui lebar dari substrate dan groundplane didapatkan nilai sebesar 47,99 $\mathrm{mm}$. Sedangkan untuk mengetahui panjang dari substrate dan groundplane didapatkan nilai sebesar 52,29 $\mathrm{mm}$. Dari hasil perhitungan diatas didapatkan hasil parameterparameter dalam perancangan antena mikrostrip bowtie MIMO $2 \mathrm{X} 2$ dengan nilai seperti pada Tabel 2.

Tabel 2 Parameter antena.

\begin{tabular}{|c|c|c|}
\hline Parameter & Nilai (mm) & Keterangan \\
\hline A & 42,69 & Panjang patch \\
\hline $\mathbf{a}_{1}$ & 3 & Alas slot segitiga \\
\hline B & 38,39 & Lebar patch \\
\hline $\mathbf{b}_{1}$ & 8 & Tinggi slot segitiga \\
\hline $\mathbf{C}$ & 7 & Lebar slot persegi \\
\hline D & 38,39 & Panjang satch persegi \\
\hline $\mathbf{E}$ & 3 & Panjang slot persegi \\
\hline $\mathbf{F}$ & 3 & Lebar slot persegi \\
\hline $\mathbf{H}$ & 1,6 & Ketebalan substrate \\
\hline $\mathbf{T}$ & 0.035 & Ketebalan patch \\
\hline Lf & 13,330 & 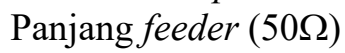 \\
\hline ls & 52,29 & Panjang substrate \\
\hline wf & 3.057 & 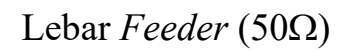 \\
\hline ws & 47,99 & Lebar Substrate \\
\hline
\end{tabular}

\section{Hasil Simulasi dan Pengukuran Antena}

\subsection{Hasil Simulasi Menggunakan CST}

Dari hasil simulasi antena MIMO, didapatkan return loss S11, S12, S21, dan S22. Untuk nilai S11 dan S12 memiliki nilai dan bentuk return loss yang sama yaitu sebesar $-46,9 \mathrm{~dB}$, sedangkan untuk S12 dan S21 bernilai $-35,2 \mathrm{~dB}$ pada frekuensi $5.5 \mathrm{GHz}$, seperti pada Gambar $5-8$.

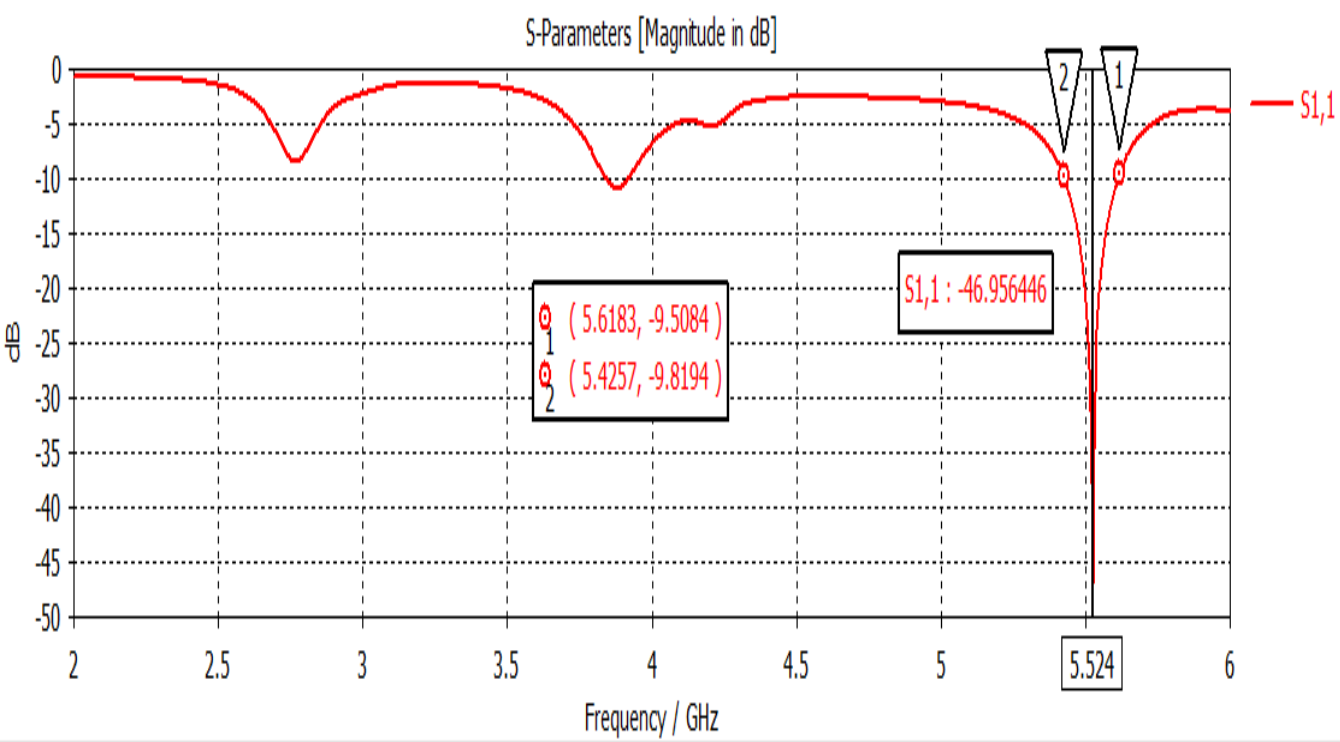

Gambar 5. S11 Hasil simulasi antena. 


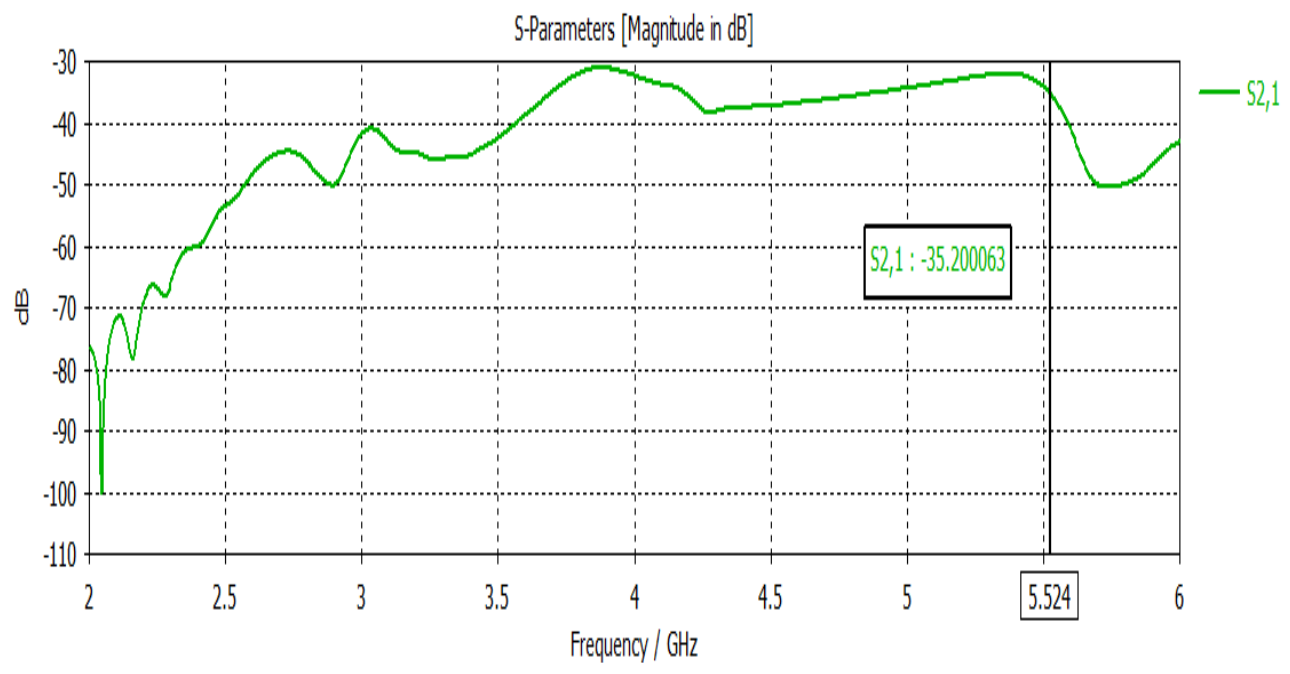

Gambar 6. S12 Hasil simulasi antena.

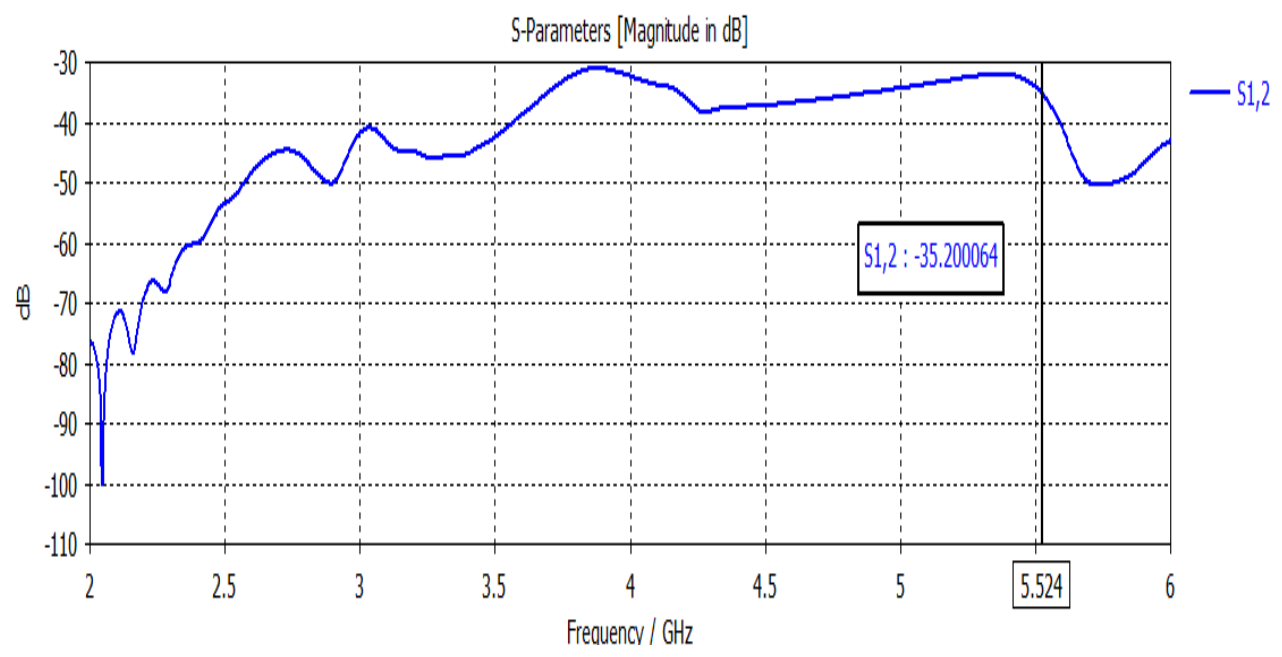

Gambar 7. S21 Hasil simulasi antena.

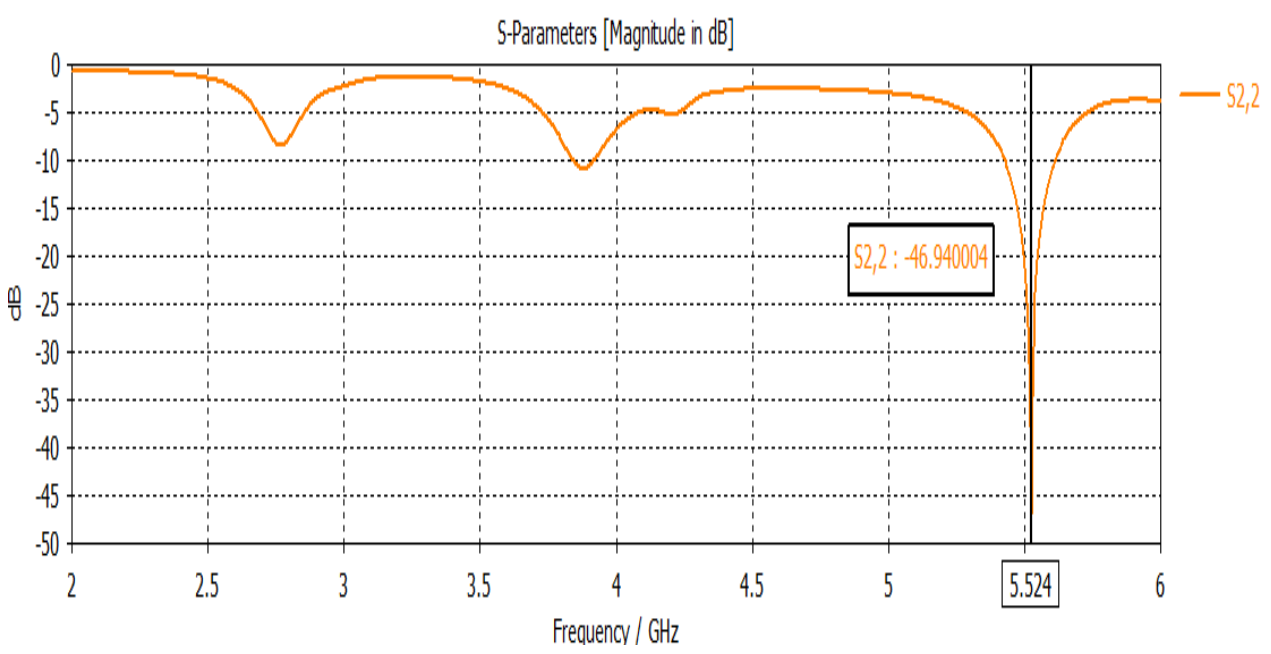

Gambar 8. S22 Hasil simulasi antena. 
Untuk hasil VSWR dari antena yang telah disimulasi bisa dilihat seperti Gambar 9-10.

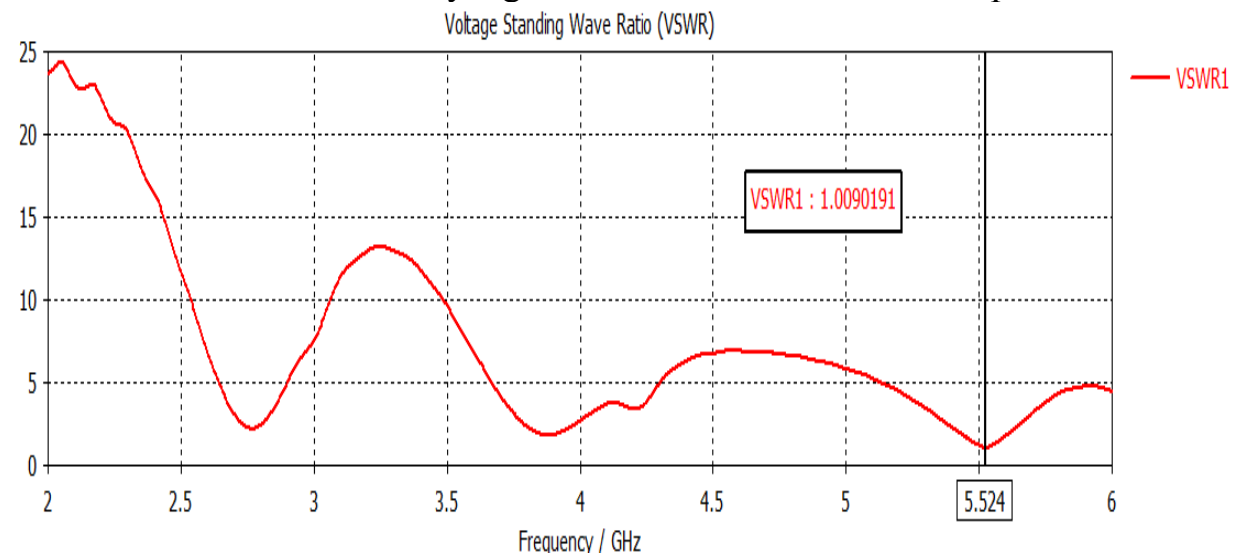

Gambar 9. VSWR 1 Hasil simulasi antena.

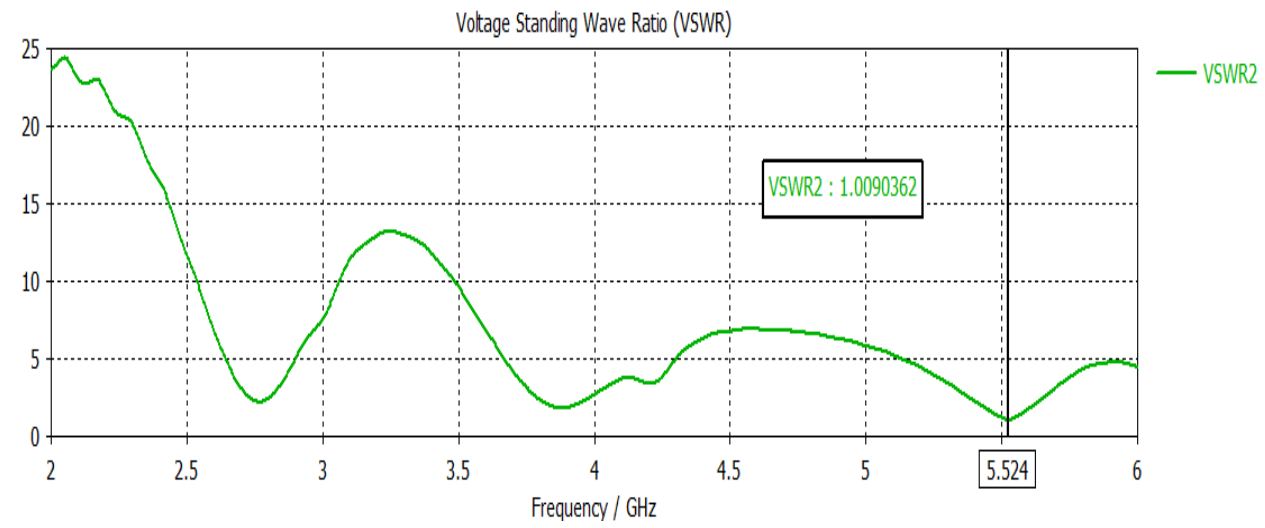

Gambar 10. VSWR 2 Hasil simulasi antena.

Dari hasil simulasi didapatkan frekuensi kerja dan parameter yang diinginkan, dengan merubah beberapa parameter seperti nilai lebar dan panjang feeder, patch, dan ukuran dari slot yang ditambahkan. Untuk mendapatkan hasil yang diinginkan dilakukan optimasi dengan beberapa cara yaitu sebagai berikut:

a. Pada antena tanpa slot diberikan slot, frekuensi kerja bergeser dari 2,4 $\mathrm{GHz}$ menjadi 5,5 GHz. Adapun nilai S-parameter tanpa slot adalah $-21,254 \mathrm{~dB}$ dan setelah ditambah slot menjadi -44,269 dB. Sedangkan untuk gain dari -0,35 setelah ditambah slot menjadi 3,82. Sementara untuk bandwidth meningkat dari 66,1 MHz menjadi 184,4 dB. Penambahan slot menyebabkan peningkatan intensitas radiasi pada antenna sehingga gain bertambah.

b. Setelah ditambahkan slot kemudian dimensi slot diubah dengan beberapa ukuran untuk mendapatkan hasil yang berbeda serta mendekati kepada frekuensi yang diinginkan. Pertama dengan merubah dimensi single slot segitiga dengan ukuran $(\mathrm{P}=10 \mathrm{~mm}, \mathrm{~L}=5 \mathrm{~mm})$ dan dimensi dual slot segiempat $(\mathrm{P}=5 \mathrm{~mm}, \mathrm{~L}=3 \mathrm{~mm})$ dengan hasil simulasi mengalami penurunan return loss, bandwidth, dan gain. Percobaan kedua merubah dimensi single slot segitiga $(\mathrm{P}=12 \mathrm{~mm}, \mathrm{~L}=7 \mathrm{~mm})$ dan dual slot segiempat $(\mathrm{P}=7 \mathrm{~mm}, \mathrm{~L}=5 \mathrm{~mm})$ dengan hasil yang didapat yaitu return loss menurun akan tetapi bandwidth, dan gain meningkat.

c. Percobaan ke-3 yaitu merubah antena single elemen menjadi antena MIMO 2X2 bowtie dengan menggunakan single slot segitiga dan dual slot segiempat. Hasil simulasi yang didapatkan yaitu nilai return loss, bandwidth kembali meningkat sedangkan untuk gain hanya sedikit lebih rendah. Perbandingan optimasi antena dapat dilihat pada Tabel 3. Struktur antena bowtie yang dasarnya menggunakan patch triangular telah meningkatkan 
parameter antena karena antenna patch triangular diketahu memiliki distribusi intensitas medan listrik yang lebih seragam pada patch sehingga hal ini memperbaik nilai-nilai dari VSWR, Return Loss, maupun gain.

d. Nilai return loss yang dihasilkan akan mempengaruhi nilai dari VSWR, semakin tinggi nilai dari return loss maka akan semakin baik nilai VSWR yang dihasilkan hingga mendekati nilai ideal yaitu 1 . Hal ini disebabkan karena nilai koefisien refleksi $(\Gamma)$ yang semakin kecil sehingga nilai VSWR menurun. Hal serupa juga terjadi dengan nilai return loss, jika return loss semakin kecil maka koefisien refleksi $(\Gamma)$ juga semakin kecil sehingga mengakibatkan terjadinya perubahan nilai pada VSWR.

e. Penambahan slot pada antena mempengaruhi nilai frekuensi antena serta menambah nilai return loss menjadi semakin tinggi dan membuat bandwidth menjadi semakin lebar. Akan tetapi jika menambah lebar ukuran Slot yang telah ditambahkan akan mempengaruhi nilai return loss menjadi turun serta akan mempengaruhi nilai dari VSWR, semakin besar ukuran slot semakin kecil nilai dari return loss. Jadi ukuran slot harus pas dan tidak terlalu besar.

\subsection{Hasil Pengukuran Menggunakan VNA (vector Network Alalyzer)}

Setelah melakukan simulasi didapatkan hasil antena MIMO 2X2 dengan menggunakan patch bowtie serta menambah kan dual slot segiempat dan single slot segitiga dengan mendapatkan hasil simulasi seperti nilai dari frekuensi kerja, return loss, VSWR, gain, dan pola radiasi. Untuk dapat mengetahui perbandingan antena hasil simulasi dan antena yang sudah difabrikasi dilakukan pengukuran di lab elektro Universitas Jenderal Achmad Yani menggunakan VNA (Vector Network Analyzer).

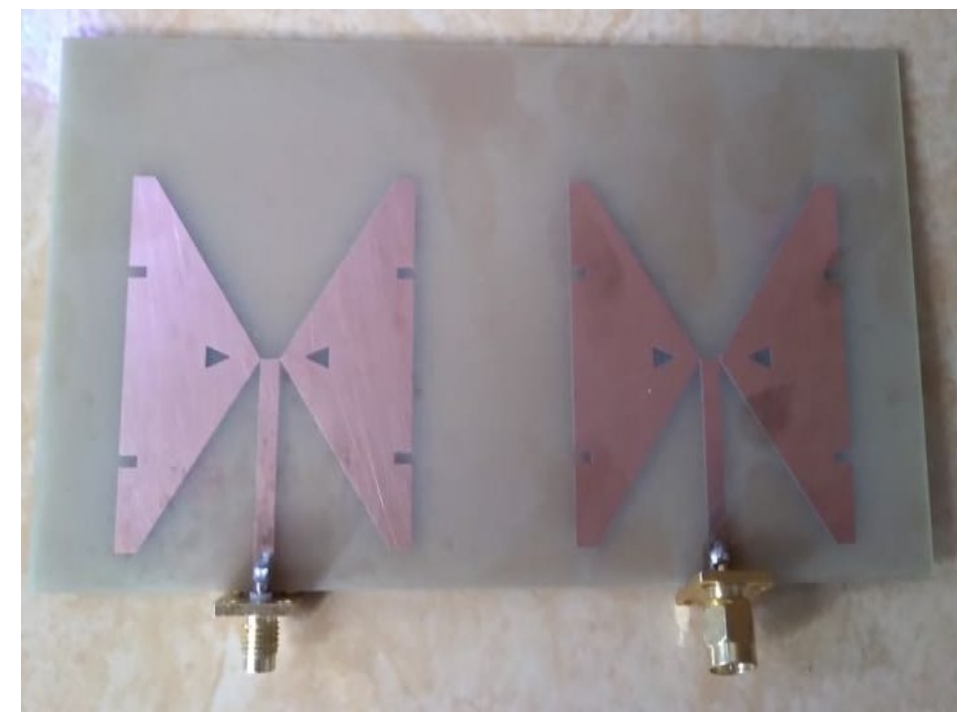

Gambar 11. Tampilan antena MIMO 2 X2 bowtie dari depan.

Gambar 11. merupakan antena telah difabrikasi yang kemudian diukur menggunakan VNA (vector network analyzer) untuk mengetahui hasil pengukuran dari S-Parameter, karena antena berjenis MIMO jadi didapatkan hasil return loss seperti S11 ,S12, S21, dan S22, VSWR 1 dan VSWR 2. Telah didapatkan nilai S-parameter (S11 ,S12, S21, dan S22) dari hasil pengukuran menggunakan VNA (vector network analyzer) pada frekuensi $2 \mathrm{GHz}-6 \mathrm{GHz}$ yang didalamnya terdapat nilai return loss, bandwidth dan VSWR dan dapat dilihat seperti pada Gambar 12-15. 


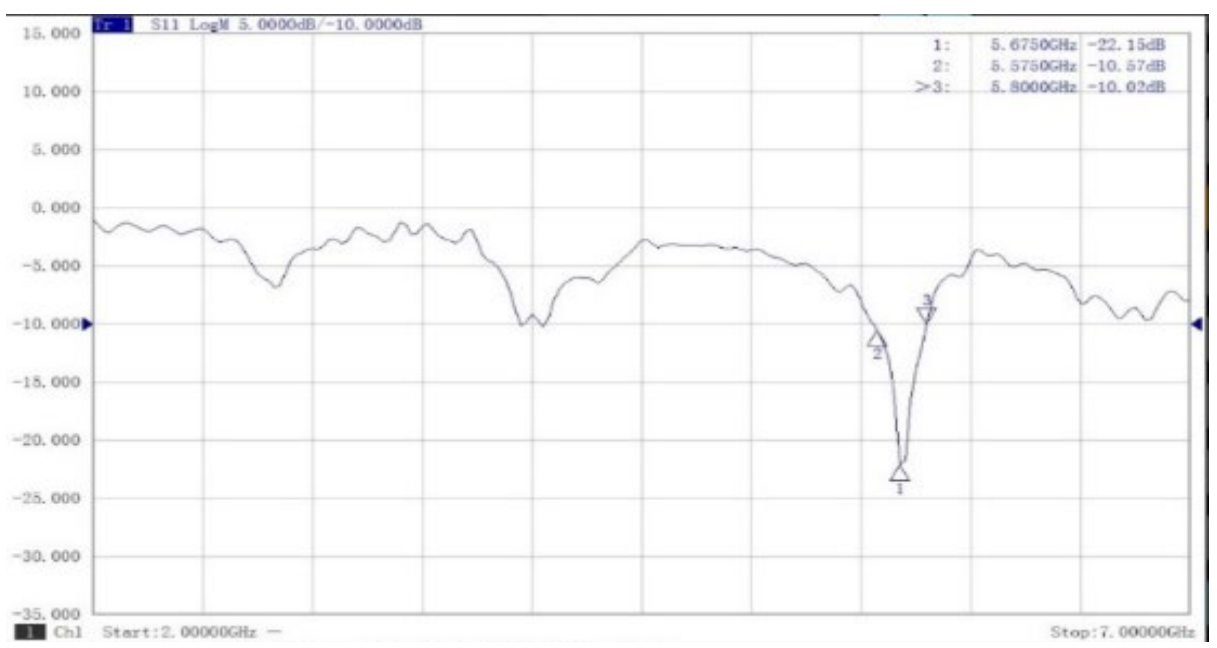

Gambar 12. S1 1 hasil pengukuran antena.

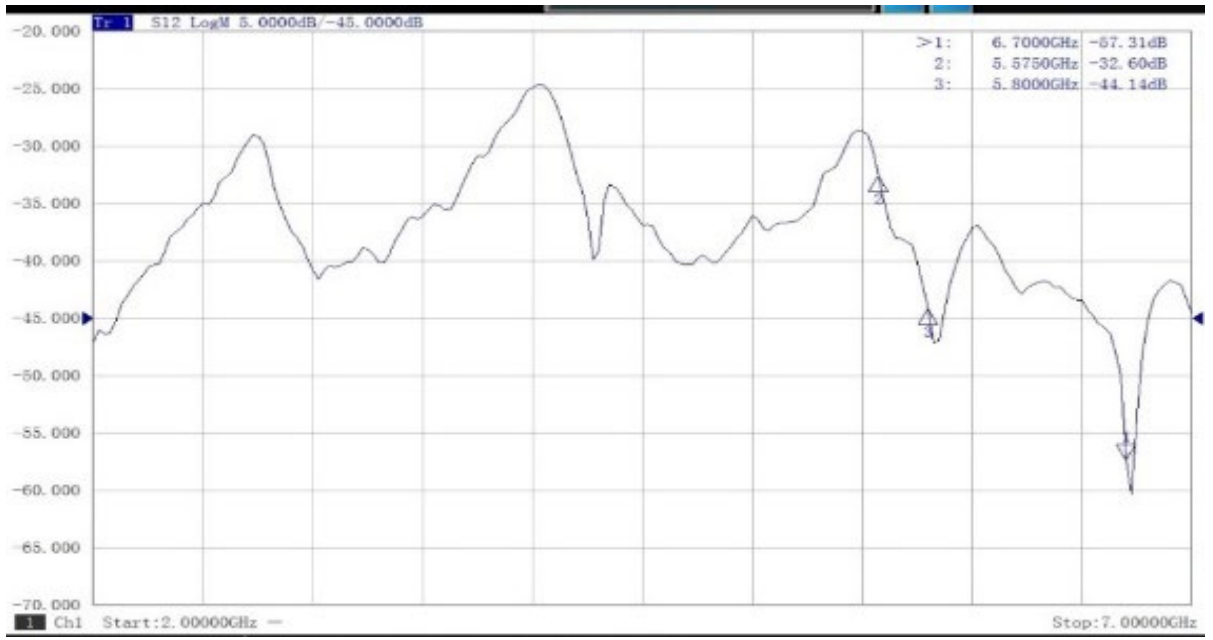

Gambar 13. S12 hasil pengukuran antena.

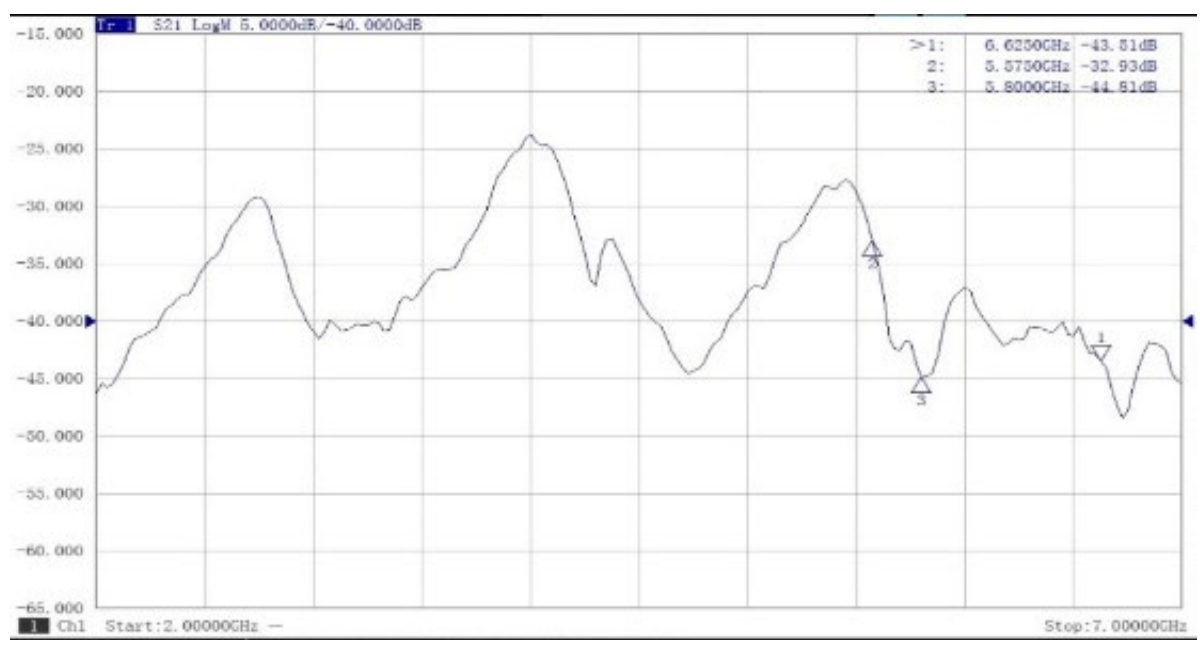

Gambar 14. S21 hasil pengukuran antena. 


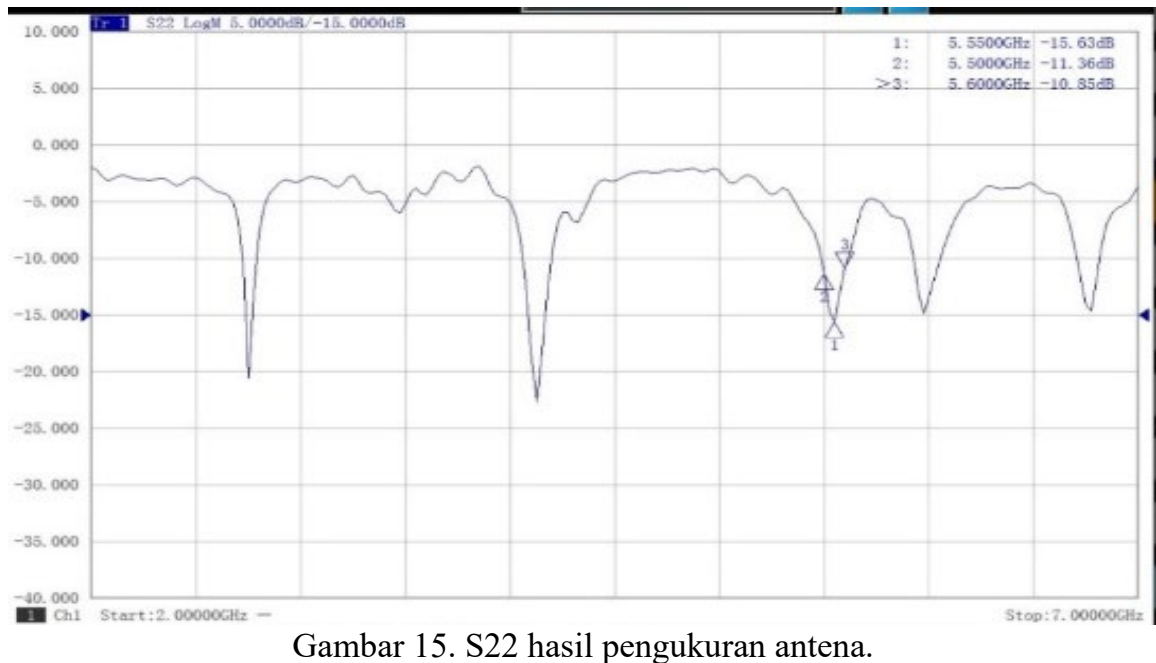

Sedangkan untuk VSWR dari antena yang difabrikasi bisa dilihat seperti Gambar 16 dan Gambar 17.

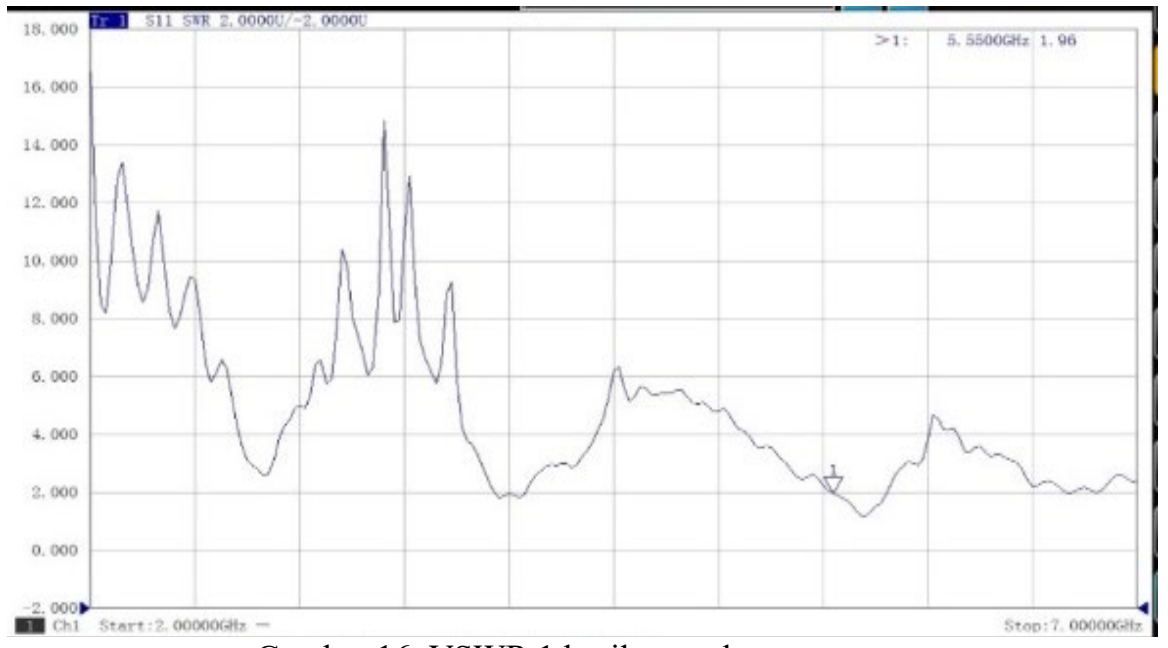

Gambar 16. VSWR 1 hasil pengukuran antena.

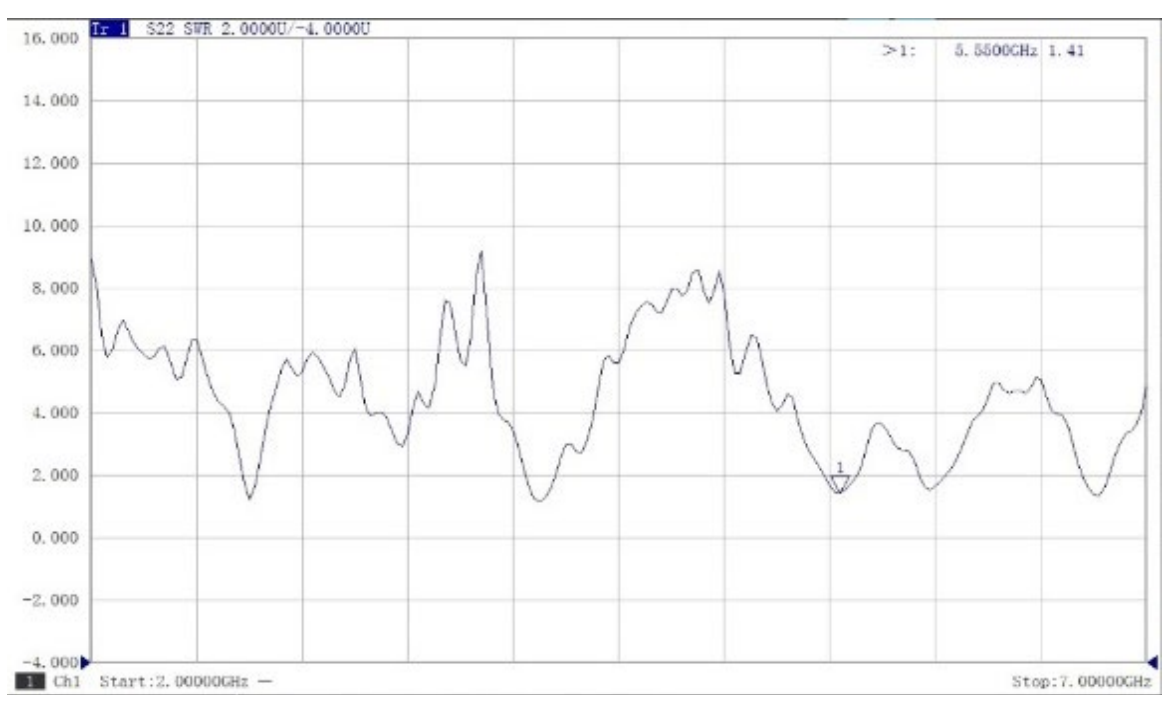

Gambar 17. VSWR 2 hasil pengukuran antena.

ISSN (e): 2540-9123

ISSN (p): 2502-1982 
Untuk dapat mengetahui perbandingan antena hasil simulasi dan antena yang sudah difabrikasi dilakukan pengukuran menggunakan VNA (Vector Network Analyzer) dan ada perbandingan antara antena yang disimulasi dengan antena yang telah difabrikasi. Hasil perbandingan dapat dilihat dari Tabel 3.

Tabel 3. Perbandingan antena.

\begin{tabular}{ccccc}
\hline \multirow{2}{*}{ Parameter } & \multicolumn{2}{c}{ Simulasi } & \multicolumn{2}{c}{ Pengukuran } \\
\cline { 2 - 5 } & Antena 1 & Antena 2 & Antena 1 & Antena 2 \\
\hline Frekuensi kerja & $5150-6100 \mathrm{MHz}$ & $5150-6100 \mathrm{MHz}$ & $5750-5800 \mathrm{MHz}$ & $5000-6000 \mathrm{MHz}$ \\
Frekuensi tengah & $5524 \mathrm{MHz}$ & $5524 \mathrm{MHz}$ & $5673 \mathrm{MHz}$ & $5500 \mathrm{MHz}$ \\
Return loss & $-46,954$ & $-46,940$ & $-22,32$ & $-15,63$ \\
Insertion loss & $-35,2$ & $-35,2$ & $-43,5$ & $-43,5$ \\
bandwidth & 192,2 & 192,0 & 50 & 100 \\
Gain & 3,11 & 3,11 & - & - \\
VSWR & 1,00 & 1,00 & 1,96 & 1,41 \\
\hline
\end{tabular}

Dari hasil pengukuran menggunakan VNA bisa dibandingkan hasil return loss dari antena yang difabrikasi yaitu sebesar $-22,32 \mathrm{~dB}$ pada frekuensi $5575 \mathrm{MHz}$ untuk antena 1 , dan untuk antena 2 return loss bernilai -15,63 dB difrekuensi $5500 \mathrm{MHz}$ sedangkan lebar bandwidth lebih kecil dari hasil simulasi yaitu $50 \mathrm{MHz}$ untuk antena 1 dan $100 \mathrm{MHz}$ untuk antena 2. Nilai insertion loss kedua antena dari hasil pengukuran nilai S21 yaitu sebesar $-43,5 \mathrm{~dB}$. Untuk nilai VSWR dari antena yang diukur memiliki perbedaan nilai untuk VSWR 1 yaitu sebesar 1,96 dan VSWR 2 sebesar 1,41. Hasil dari simulasi nilai return loss memiliki nilai yang sama yaitu sebesar $-46,9 \mathrm{~dB}$, untuk antena 1 dan 2 nilai insertion loss yaitu sebesar -35,2 dB. Lebar bandwidth hasil simulasi dari kedua antena lebih baik yakni sebesar 192,2 MHz, nilai VSWR antena 1 dan antena 2 memiliki nilai yang sama yaitu 1,00 serta memiliki nilai gain yang sama yakni sebesar 3,11 dBi. Jadi telah diketahui hasil pengukuran dan hasil simulasi tidak sama persis nilai dari return loss, bandwidth, dan VSWR dikarenakan adanya perubahan dimensi dan permetivitas bahan antena yang difabrikasi yang menyebabkan ketidasamaan nilai parameter dari hasil pengukuran dan simulasi. Adapun nilai gain dan pola radiasi dari antena yang telah difabrikasi tidak dapat diketahui karena keterbatasan alat ukur.

\section{Kesimpulan}

Penggunaan slot pada patch bowtie telah berhasil menggeser frekuensi kerja antena dari 2.36 menjadi $5.52 \mathrm{GHz}$ yang diperoleh menggunakan metoda uji coba simulasi. Selain itu penggunaan slot juga menaikkan nilai dari parameter VSWR, S11, gain, dan bandwidth Antena. Hasil dari pengukuran antena MIMO dapat dilihat terjadi perbedaan dari parameter antena 1 dan 2. Hal ini dianalisa adanya ketidaksamaan ukuran dari antena 1 dan antena 2, Adapun hasil dari pengukuran didapatkan nilai return loss dari antena 1 yaitu sebesar $-22,32 \mathrm{~dB},-15,63 \mathrm{~dB}$ untuk antena 2, sedangkan untuk insertion loss antena 1 dan 2 memiliki nilai yang sama yaitu $-43,5$ $\mathrm{dB}$ dan untuk lebar bandwidth memiliki perbedaan nilai yaitu $50 \mathrm{MHz}$ untuk antena 1 dan 100 $\mathrm{MHz}$ untuk antena 2. Kemudian untuk nilai VSWR 1 didapatkan nilai sebesar 1,96, VSWR 2 sebesar 1,41 .

\section{Referensi}

[1] Fajar W A, Nachwan M A., Budi S. "Analisis Simulasi Antena MIMO 44 Susunan Persegi dan Sirkular pada Frekuensi 15 GHz".Universitas Gajah Mada".2018.

[2] Kevin A.S. , Levy O N. , Budi S.” Perancangan Antena MIMO $2 \times 2$ Array Rectangular Patch dengan U-Slot untuk Aplikasi 5G".JNTETI.2017.

[3] Asri W, Riski M F, Fadli K, "Rancang Bangun Antena Mikrostrip Mimo 2x2 Untuk Aplikasi Wifi 802.11n Di Frekuensi 2,4 Ghz". POLITEKNOLOGI.2017 
[4] A. W. R. M. F. F. Kurniawan, rancang bangun antena mikostrip mio $2 \times 2$ untuk aplikasi wifi 802.11n dan di frekuensi 2,4 GHz, e-Proceeding of Engineering.2017.

[5] Mustofa, A. Z. Analisis pengaruh penggunaan antena jamak MIMO 2x2, SIMO 1x2 dan SISIO 1x1 terhadap performansi OFDMA pada teknologi Radio Ove Fiber. Universitas Brawijaya.2015

[6] M. M. Lumembang, A. B.“Analisa karakteristik antena mikrostrip slot bowtie pada frekuensi 2,4 GHz. Universitas Hasanuddin.2015

[7] Rafelly Jhon, A. A.. Ra“Perancangan dan realisasi antena mikrostrip MIMO bowtie 4X4 pada frekuensi 1,8 GHz untuk aplikasi LTE. e-Proceeding of Engineering.2016.

[8] Widianto, B. "Perancangan dan realisasi antena MIMO berbasis mikrostrip pada frekuensi 2,6 GHz umtuk aplikasi LTE”. Telkom University.2012.

[9] Levy O N, M F H, Bambang S N, "pengembangan Antena Fleksibel Mikrostrip Bowtie", TELKA,2019

[10] M. K. A. Rahim. Et al, "Bow-tie Microstrip Antenna Design". Wireless communication centre, faculty of electrical engineering. University Teknologi Malaysia, 2015. 